Analyticity and Syntheticity 
Empirical Approaches

to Language Typology

6

Editors

Georg Bossong

Bernard Comrie

Mouton de Gruyter

Berlin . New York 


\section{Analyticity and Syntheticity}

A Diachronic Perspective with Special Reference to Romance Languages

by

Armin Schwegler

Mouton de Gruyter

Berlin · New York 1990 
Mouton de Gruyter (formerly Mouton, The Hague)

is a Division of Walter de Gruyter \& Co., Berlin.

(0) Printed on acid-free paper which falls within the guidelines of the ANSI to ensure permanence and durability.

\section{Library of Congress Cataloging in Publication Data}

Schwegler, Armin, 1955-

Analyticity and syntheticity : a diachronic perspective with special reference to Romance languages / by Armin Schwegler.

p. $\mathrm{cm}$. - (Empirical approaches to language typology ; 6)

Revision of the author's thesis (Ph. D. - University of California, Berkeley, 1986).

Includes bibliographical references and indexes.

ISBN 0-89925-332-6 (cloth : acid-free paper)

1. Romance languages - Syntax. I. Title. II. Series.

PC201.S38 1990

$440-\mathrm{dc} 20 \quad 90-49317$

Deutsche Bibliothek Cataloging in Publication Data

Schwegler, Armin:

Analyticity and syntheticity : a diachronic perspective with special reference to Romance languages / by Armin Schwegler. - Berlin;

New York : Mouton de Gruyter, 1990

(Empirical approaches to language typology ; 6)

ISBN 3-11-011245-0

NE: GT

(C) Copyright 1990 by Walter de Gruyter \& Co., D-1000 Berlin 30.

All rights reserved, including those of translation into foreign languages. No part of this book may be reproduced or transmitted in any form or by any means, electronic or mechanical, including photocopy, recording, or any information storage and retrieval system, without permission in writing from the publisher.

Printing: Ratzlow Druck, Berlin. - Binding: Dieter Mikolai, Berlin. Printed in Germany. 
The aim of science is to seek the simplest explanation of complex facts. We are apt to fall into the error of thinking that the facts are simple because simplicity is the goal of our quest.

Alfred North Whitehead:

Concept of Nature 
